IRA-International Journal of Management \& Social Sciences

ISSN 2455-2267; Vol.04, Issue 01 (2016)

Institute of Research Advances

http://research-advances.org/index.php/RAJMSS

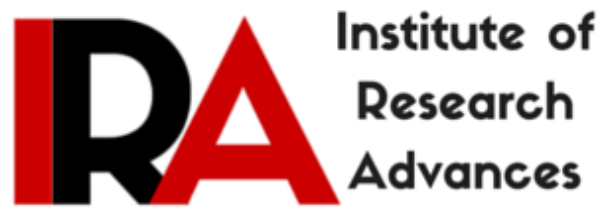

\title{
Immigrants Identity Crisis in The Lonely Londoners
}

Saman Abdulqadir Hussein Dizayi

PhD Student, Istanbul Aydin University, Turkey.

DOI: http://dx.doi.org/10.21013/jmss.v4.n1.p17

How to cite this paper:

Dizayi, S. (2016). Immigrants Identity Crisis in The Lonely Londoners. IRAInternational Journal of Management \& Social Sciences (ISSN 2455-2267), 4(1). doi:http://dx.doi.org/10.21013/jmss.v4.n1.p17

(C) Institute of Research Advances

\section{(cc) EY-NC}

This works is licensed under a Creative Commons Attribution-Non Commercial 4.0 International License subject to proper citation to the publication source of the work.

Disclaimer: The scholarly papers as reviewed and published by the Institute of Research Advances (IRA) are the views and opinions of their respective authors and are not the views or opinions of the IRA. The IRA disclaims of any harm or loss caused due to the published content to any party. 


\section{ABSTRACT}

This paper looks into the novel The Lonely Londoner by Samuel Selvon that is reviewed as a postcolonial novel. The paper examines the plight of the Caribbean migrants who traveled to England hoping that the fairytales they had been fed on by the colonizers were realistic and confined to England. The study considers the predicament that these migrants went through in their colonizer's homeland where they felt despised and derelict against their immense hope that they had when they were leaving their native islands. The paper also looks into the theme of mimicry as posted by Homi Bhabha in his postcolonial theory. By considering the view of Bhabha, the paper looks deeply into the theory advanced and how it is consequently used in the novel. Thus, the paper investigates how mimicry and hybridity have been portrayed in the novel The Lonely Londoner, and at the same time looks into how Samuel Selvon typically applied them to express his postcolonial discourse in his work.

Keywords: Postcolonialism, Identity, Mimicry, Unhomed Condition, Homi Bhabha, Postcolonial Novel.

\section{Introduction}

B lack British novel is a story about the suffering of immigrants in Britain from West Indians. The literature is composed of work by authors from former British colonies in Africa, Asia and also some literature by the Caribbean. The work in Black British Literature has similarity regarding disillusionment with England, mostly about London and what London has to offer to the black immigrants. The writers in Black British novel focuses on the inhumane act blacks went through in England which also included the desire to realize self-identity. The novel can be termed as the origin modern world; the claim is supported by other historical documents.

The writing culture that was introduced which had a great influence in the change of the management practices that were induced during that time. The period of the Empire in the British West Indies was induced with the writing skills that made them look like they were Britain too. They adopted the speaking in English and also the use of the literature styles together with the listening capabilities. According to what they believed it was past, to be a British had the meaning that you should be a white skinned person. The West India immigrants had however stayed in the Britain where they helped build the multicultural Britain. Sam Selvon was also included in the immigrant's population of the mass movement from the West Indies. His use of dramatization brought up an important increment in the Britain's cultural value. It helps the immigrants have the value and importance to face the challenges that they had from their daily activities. Selvon gives his right in the engagement of the Centre dominant literary culture as a member of the group fighting for the immigrant's freedom. His urge in writing a book took the best knowledge where he knew that it could serve as a wall between the human life and all other stories that are given. Selvon spent most of his career writing about the suffering blacks encountered in London. In his novel the lonely ranger, Samuel Selvon expresses his anger and disappointment the black immigrant experienced in London and neighboring towns. In this paper, we will examine how Selvon portrayed the identity crisis in the novel Lonely Londoner.

An identity crisis can be said to be the main theme of the novel though the novel offers hope to West Indians migrants through adaptation. Selvon is optimistic that change will occur plus also societal reformation that will make it possible to achieve the London he described. It is evident that London is one of the most cosmopolitan urban centers in the world. The number of black living in England continued to increase year by year after the World War I ended. To curb the increasing number of black migrant, a regulation to reduce the number by half was enacted. The 
regulation was enacted to prevent London from flooding with black immigrants. Which was the case in the late nineteen century, when white immigrants flocked in England. The British government adopted austerity measure to prevent the repetition of what happened in the late 19th century where white immigrant stormed London. An example of regulation employed to curb the number of ever increasing black migrant included confining them to inferior jobs. Another regulation is making houses inaccessible by the black migrant forcing them to stay in temporal houses. The measures were employed to push black immigrants to the street and discourage black from migrating to England. The police were instructed to make the life of the black uncomfortable through chasing them making the situation worse. Ruth Glass interpret the instruction from the White Defense League as a mandate to send the black immigrants back home.

\section{Background}

Selvon's commencement of the novel through the interplay between the reality and illusoriness of the London city. The author is a part of an immigrant from the Caribbean, who transformed the England's metropolitan after the end of the war. To survive in Britain, Selvon had to adjust his identity from the old traditional practices of the Caribbean people. This re-appropriation is what Bhabha refers to as mimicry where the narrator mimics the ways of the colonizers so that they can fit into the ways of their motherland colonizers. However, the expectations that the migrants had been totally wrecked when they arrived in London and despite them mimicking their colonizer, they were unwelcome in England and this led to a transformation that changed the expected channel that they had or that their colonizer had. Homi Bhabha refers to this mutation as hybridity where the character of the black Caribbean migrants changed from what they and the colonizers distinctly expected, to a character that tries to fight the agents of colonialism. The case where Selvon and other people of that time being colonized is against the odd, as no one sees the act as fit. The statement by Naipaul that one was forced to adopt a new identity from the real complement Selvon conditions in London. According to Selvon, the reality in London was far the expectation. For instance, being colonized when other are celebrating Christmas is inhumane. Christmas is a holiday where people show love to one another, this is in contrast to what was happening in London, and it's metropolitan due to racial discrimination [1] (Weedon, 2004, 91). Naipaul clearly reveals the situation, he believed that black had no any other option but to imitate the destructive lives of whites to survive in Britain.

\section{Postcolonialism in The Lonely Londoners}

The magnificent awakening of the Caribbean people took place in the 19930s and included the fiction by Naipaul largely provide a less austere conclusion for it stands for Caribbean immigrant working together successfully to show the world their real identity and not the one portrayed by their former colonial masters. They succeed in their quest to show the world that their Caribbean life can be understood just like any other. During the time when Derek Walcott started working as an author in the late 1940s, the use of a word like "breadfruit" in poetry was illegal according to the British government. The word could be literally to means that the life of the colonies was equal value to that of the colonizers.

The struggle by the immigrant from the Caribbean is only a part of the literature. Indemnity crisis was not limited to an immigrant from the Caribbean but also for another part of the world such as Asia and Africa. Most if not all of the authors in literature at one time in their lives were forced to leave their native countries to Britain. Authors migrated from their birthplace to London and other metropolitan centers. By the 1950s, Britain was home to most of the immigrant from the Anglophone, to some individual the migration was an attempt to colonize their former colonial master. The majority of the immigrant to Britain welcomed the possibility of abandoning the illusoriness of the colonial periphery for the presumed reality of the life in London and another metropolitan center. In this center, it as was assumed it was where true living took place.

On the arrival in London or other metropolitan centers, immigrants were always amazed by these cities. At times, even the news that one will be going to the London amazed the blacks. For 
instance, in The Lonely Londoners, Galahad is mesmerized by the news that he will be visiting London, he stated that he felt like a king living in London[2] (Selvon 84-85). In the novel Galahad reveal identity crisis when he state that he torn between a white mask and dark skin. From the state, there is some hope for Indians becoming truly modern and having a say in their destiny. Every time a racial dispute erupt, Galahad's self-identity is unhinged. Galahad goes to the extent of blaming his color for all the troubles he goes through. At the point he doesn't want to be black, he blames the color for the discrimination that he goes through. Galahad instead of realizing that it is the system that is broken he blame color for the mistreatment. Great Britain was popular to the West Indians; one didn't require to have visited Britain to know it. The information about England was acquired mostly through the education system, mass media, speculation, and exaggerated stories for thus who were lucky enough to have visited Britain. The same applies to Selvon, who knew Britain's language, history, common sports, and available religion even before he had relocated to England. After the arrival in London, Selvon found out most of the information he had about England were just mere speculation and did not meet his expectation he had before visited London. As an immigrant, Selvon encountered a different England from his expectation and referred to them as actualities. The Britain the immigrants encountered was different from that of the education system and also different from the one of story books. England was a much-complicated place from the shops to the street.The stronghold of The Lonely Londoners is in the presentation of London from the immigrant point of view. A poor black Indian is the one who develop into the authoritative anthropological detective. It is the duty of the narrator to explain to the reader the weird habits of the native London resident. Young boys both migrants and West Indians have the privileged perspective of the London; boys have the access to the entire city due to the mobility. According to Selvon, Londoner do bother themselves to what is happening even to their neighbors or how they are doing [3] (Selvon 73). It indicates how busy most people are in London trying to meet the ends wants.

It is through Selvon's perspective that he gain rich information about London culture and also enable him to explore Londoners relate to each other with the minimal human contact he encountered in Britain. Besides, Selvon explores how rich and poor relate to each other and also black migrants and the white. Selvon states that when the thing does not work out for the poor, the rich people are less concerned. Selvon can identify city's dispossessed, white and also black immigrants, generating pictures that are similar to the memory he has of black and white photograph that belonged to either Bill Brandt or Bert Hardy.

According to the narrator London, operate as an uninviting, separate entity, and use the technology to reduce work done manually. The explanation complements the description of London made by Moll Flanders. Moll state both the good and bad fortune are random in London. They further state there are some events that do exist, and the residents have no control over. The economic life in London is characterized by a chain of food and shelter search. The black immigrants and also the white women have less or even no right. The two and especially the blacks are treated like someone own them. The London have limited opportunities for the black immigrants and also white women. Thus, they are forced to be submissive to white men. Through reasoning, Moses break down how he uses his time. He discovers that the trend is have been the same all time of the year be it summer or winter the routine is sleeping, eating, and working. Moses is too busy to find some time spend to sunbathe alone and remain to just a wish [4] (Selvon 129-130). Winter evening in London is characterized by silence in the neighborhood, stale porridge, and gas rings that are inactive. The narrator is induced to despise as he was waiting to relax, farcically, outside the house. 


\section{Review of Identity Crisis in the Lonely Londoners}

The Lonely Londoners novel presents some identity crisis who employs a various approach to surviving as immigrants and in the process of doing so they establish a risky hold on the London life. A refrain that reappear throughout the novel turns on the perseverance that the old identities that the immigrants brought with them to London. The old identity of Cap is characterized by the use of fashion style from either Spain or Kingston, lack of cooperation, untransformed. Cap also use her fashion style to disappear in moments when he does not want to be noticed.Harris have a character that are contrary to those of Cap. Harris is an early model of what Naipaul defines as a mimic man; he is obsessed with earnings respect and adopt English traditions to the maximum. Galahad, as we have discussed above is drawn to the partying, engaging romance, and more specifically he is attracted to Piccadilly's Eros. Masculinity in the novel is indicated by the amount of time men in the novel uses to hustle for pussy. The considerable time spends in hustling for pussy indicate the lust of sex among the men in the novel. Women are viewed as sex objects by men; this is indicated by the author use the term hustling for pussy instead of other terms such as courtship. From this point of view, Galahad is more assiduous compared to other West Indians living in London. Samuel Dickson Selvon died at the age of 71 years. His origin can be anticipated to an Indian family from the east. He came from a Christian family where his dad was from the Madras, and his mother came from the ScottishIndian region. His early education was done at the San Fernando, Naparima College till when he was grown up the teen at the age of fourteen where he was employed. He was employed at the Royal Navy as a technical operator during the start of the World War II. He left the job and went to the Trinidad Guardian and also went to the Indian Embassy to work as a clerk. He had an advantage after working in the $\mathrm{BBC}$ which was a cooperation that used to produce some of the TV scripts. During the beginning of the post-war, he opted to go to England where he was lured to join a certain complacency and acceptance of terms and condition of a certain corporation. In 1978, he migrated to Canada where England became the long living place for him in his history. Previously, he had become a writer after he wrote his first novel in 1952. This writing move was motivated by the move he made to London. He published his best novel by the title, lonely Londoners which had the theme on the naïve immigrants who existed in the London. He did many other novels during his adventure that included the turn again tiger and the ways of the sun. During this writing era, he had a contribution to the Caribbean literature where he presented most of the unforgotten characters in his writings such as the Moses. Selvon was regarded as an adventurer's leader who was derived by the use of his idioms that had the reference to the talents. This aspect made most of the writers in the era encouraged in the writings of books and information on the people's culture. He had the most use of humor combined with the empathy that was adopted by most of the writers in western India which become a major style and art of writing [5] (Smith, 2004, pp. 83). Many people had rated the works of the Selvon regarding him as part of them especially when he moved to Britain from the Caribbean. Also, the London Literature grounds were affected and had the influence in the introduction of certain aspects from the writings of Selvon. The writings of the season have impacts on the London literary scenes and the characteristics of the post-colonial era. It gives a clear picture on the advantages of the sharing of labor in the colonial migrants who exist.

\section{Overview of Postcolonial Theory by Homi Bhabha}

In Bhabha's essay "Of Mimicry and Man" in The Location of Culture he posits that the colonial subject's mimicry of his colonizer does not produce a replica of the colonizer, rather this mimicry produces something that the colonizer does not anticipate. The colonial takes into himself the colonizing image and merges it with his Africanism or Indianism and becomes something new and different - a hybrid creature that subverts the colonial project. As he puts it in one essay, 'I have tried ... to rename the postmodern from the position of the postcolonial. Bhabha's work on 
contemporary culture valorizes the hybridity of migrant and diaspora culture within what is conceived as the homogeneous space and time of the nation. Bhabha's employs the technic of building on the diaspora traditions and culture practices to try and break the economic and social barriers that have existed for generations. Our discussion here will focus on the implications of this approach for thinking migrants, diaspora and the nation. Bhabha understands the predicament of the new multi-ethnic and multi-cultural society of postwar Britain within the framework of 'the nation as narration' developed in the time of the narrative. Here, the current state is interpreted as the strategy that has the claim of the construction of new together with the long known events. The understanding of any nation's narrative is achieved together with the suppression of the differences in culture and identification. Nevertheless, Bhabha claims that normalizing act of history introduces a provisionally variable of any give society that make it superior to other traditions [6] (Bhabha, 1994, pp. 215).

In the novel the speaker shows harmony and realization of his identity, the native identity that is the foundation of the society the narration comprises of telling stories and at the same time making unity among individuals and have an identity in the nation. In an aim to unify, there will be the buildup self-identity that will be the base of all the factors. The position of the narrator is placed in another place that will have the chances of being undermined. The distance that is built in the narration process and the identity-seeking will be already be embedded in the stability of the narrator. That is, although the nation claims mastery because its definition is supposed to be integral and self-sufficient, an expression of its meanings, origin and destiny, in fact this unity and mastery is impossible. As per the Bhabha, the unfeasibility of the existence of unity and totality is the essential drives that the speaker of the society towards racial segregation and the stereotyping of individuals depending on their color unlike the previous to shoreline up the delusion of its wholeness. Being free from hostility toward each other will in the worst case scenario provide a fictional of wholeness. In this case Bhabha considers the chapter of an individual's black skin and also having a white mask that is the foundation to Hall. It is also a clear indication of Fanon's identity crisis despite the fact that the novel concentrates on the change from the experience the colonial played during colonization to their role of transforming the world. The blacks are considered as inferior human being of lesser value compared to the whites. The animal is the Negro, it is bad, it is mean, it has an ugly look; it's too cold, it is shivering because of the cold, the little boy is afraid because he is in fear of the animal'. The aggressive other ting performed by the discourse of the stereotype thus involves the de-linkage and re-linkage of elements within the signifying chain: where in the Antilles the colonial subject's crisply pronounced French and smart dress had signified frankness and belonging to the nation, now in the metropolis its appearance signifies a savagery that defines the boundary of the nation. This strategy is for Bhabha fatally flawed and proves to be its undoing [7] (Dawson, 2007). The act of generalization is used in the fictional creation of a stereo type that has some similarities the white, it is revealed by the speakers statement, 'By wilderness acceding, colonizer's fantasies, reveals the aspect of fantasy in the arena (as desire, defense) of that mastery position'.The nation's desire for unity and wholeness, then, is a construction that requires - and so is in a sense dependent on - the fantasy of 'the stereotyped other,' a revelation that for Bhabha has a profound political force. 'The signs being unreliable introduces complexity in the text. His argument comes when there is the political orientation of the judgments and even supply agencies. 'My contention', Bhabha writes, is that by 'eluding resemblance', or identify with the narrative of 'nationless', the figure of the migrant 'produces a subversive strategy of subaltern agency', that functions as 'a pulsation incident' or 'a split-second' moment of disruption within the master narrative of the nation. 


\section{Evidence of identity crisis in The Lonely Londoners based on Homi's postcolonial theory}

In the novel The Lonely Londoners, each manifestation of self-identity, mimicry and hybridity is presented in a manner that indicates they have been limited regarding their use and exploitation. Although the use of this theory developed by Bhabha is not exhaustive in the novel, there are areas that indicate of its usage in some ways. While Galahad was enjoying the luxury and appreciating his experience of traveling through London, a white child walking along his mother shouts, '... that Black man!' This is close to the tone that is evident in Fanon's Black Skin, White Masks since it is portrayed as the white despising the black man [8] (Selvon, 1985, pp.87). Furthermore, this moment of depicting the black people as the 'Other' is repeatedly evidenced over and over again, coalescing into a reified phenomenon that adopts its unmistakable presence, yet which in any case frames these characters and shapes their relations with other people. In a remarkable scene Galahad starts conversing with the color Black, as though it was a man, expressing to it that he is not the cause of botheration in the context, but rather, it was a fault of the ruthless Black thing. Galahad feels that these misfortunes have been caused by the color black, and his frustration of being isolated can be felt in his question he asks '... why the hell you can't be blue, or red or green, if you can't be white?' [9] (Selvon, 1956, pp.88). In any case, as the migrants' anxious sexual activities demonstrate, the reified typecasts of color can't be completely expressed, since it is presented in a way that it governs their lustrous transactions and cravings. The black men were recognized by white females as only a nonexistent sexual viciousness. The narrator observes that the efforts of the black men to show their politeness, their acquired civilization or even the English accent were all futile as the native Londoners never recognized them [10] (MacLeod, 2005, pp.2). For them, they wanted the black people to live up to the movies and fairytales that they had known about the black living primitively in the wilderness. Likewise, a large portion of the black men pursued the white women whom Selvon termed as 'pretty pieces of skin' [11] (Selvon, 1985, pp.102). Taking note of the fact that the novel has been condemned for its depiction of a dogmatic male perspective, Collins and Marcus argued that the perspective of the black men on the white women reveals their uncertainty and timid of their self-identity [12](Collins and Marcus, 200, pp.404). As expected in a most postcolonial literature, the novel The Lonely Londoners exhibits several unsatisfactory and frequently cruel relationships. Moses judgmentally observes that in the social world of the migrants, every single sexual relationship was objectified by the coldness of racism and discrimination that is associated with it. He laments on how difficult it was for the black migrants who wished for a normal social life of family and friendships due to the cold, unwelcoming white Londoners. Moses ends up depicting London as 'a miserable lonely city,' showing how difficult it was for the black who migrated there [13] (Selvon, 1985, pp. 130). This unbecomingness shows the disjunction between the expectations of the Caribbean migrants and what they experienced in London and England in general. Moses use of colloquial diminution Water to describe to a new immigrant where he stays is an indication of an identity crisis. In the above statement Moses take possession on a landmark in London and take pride in it stating that he has been a London resident for two years when talking to Galahad. Despite the fact that he lives in temporary accommodation, Moses avers his position as a citizen who have the matters regarding the West Indians in London at heart by helping new immigrants settle in London. From Moses act of helping West Indians settle in Britain, we can deduce that that he is still attached to the tradition of Indian people. The act can also interpret as an acceptance of western culture. Based on the fact that he helps another settle in London, thus encouraging more West Indians to visit London. Moses help integrates the fellow immigrants with the native London resident. He says that concentration of Indians in a given area will attract negative attention from the London native population. Thus, the act of dispersing new migrants should not be confused as refusing to accommodate new migrants but the act of maintaining stability. 
The novel depicts the wrecking of the sensation of identity, of belonging to the English society, and that of who is the Englishman. This is depicted by the daydreams about London whose chimera was that the streets were gold-cemented and that jobs were lucrative and easily accessible. Another illusion was the thought that the English natives were courteous, hospitable, welcoming, and of human cordiality. The elusive hospitality included the illusion that the white women were willingly ready to accept the black men into socially normal relationships [14] (Selvon, 1985, pp. 102). The Chimera of England regarding intimacy and hospitality was strong and powerful to influence the Caribbean migrants to get into London with the hope of being part of theses daydreams they all had. The West Indians, having being misled by the colonial education that no history nor romance existed in their island and that it was only plentiful in the mainland. These dreams were excruciatingly wrecked by the realism of the encounters that the migrants had when they arrived in England and London specifically [15] (Bowen-Chang, and Marsha Winter, 2008, pp. 37).

\section{Conclusion}

The novel The Lonely Londoners is an excellently written postcolonial literature that clearly depicts the woes of the West Caribbean migrants who settled in London. The migrants who moved to London during and soon after the colonization of the islands by the English men can easily account for their predicament through references to the activities that are spelled out in the setting and activities of this novel. The summary of the novel also presented looks into Selvon's aim of decolonization concerning the explorations and the display of the inhumane actions of the native Londoners. Galahad's detachment from the black skin color is an indication of how the white Londoners had disgraced and "Othered' the black Caribbean migrants who had come to their city expecting an extended hand of hospitality and acceptance. After Galahad had struggled for some time to come to terms with his predicaments of being isolated and overlooked for being black, he finally expresses his discontent by a mythical conversation with the color Black. By lamenting on the color of the migrants' skin, Selvon portrays the theme of mimicry as posted Homi Bhabha. Galahad felt irritated due to the miseries that his color that of his fellow migrants had caused them in England, a place they had high expectations in with the hope of developing their lives there [16](Kanneh, 1993, pp. 43). In his conversation with the color black, Galahad portrays mimicry in the sense that by the denial of his self-identity, he had wished that he would be like his colonizers or at least not black. Galahad's disassociation from the reality is however soon overridden by the migrants' newly acquired character that assisted them to further their intimate desires. The migrant hydrides into a stronger character that tries to conquer the hierarchy that the colonizers had set into their minds. By portrayal of sexual superiority by the young black men, Selvon evidences Bhabha's hybridity coming into the scene in this novel. The migrants also hybrids into imposing anthropological investigator despite being impoverished and loathed by the Londoners. Throughout the novel, the narrator explains the peculiar habits of a native Londoner and separates them from those of the migrant Londoners. The hybridity of the migrant also offered a higher hand to him regarding navigation into the city of London, making them travel deeper and further to explore the city in parts whose access was customarily denied for the native Londoners [17] (Selvon, 1985, pp. 73). The possibility of an individual not knowing what is happening in the house of the neighbor is high and even in the street.

\section{References}

[1] Weedon, Chris. "Identity and Belonging in ContemporarBlack British Writing." Black British Writing (2004): 73-97.

[2] ,[7 ], [8], [13], [17]

Selvon, Sam The Lonely Londoners, Penguin, England. (1956) Print. 
[5] Smith, Ian. "Critics in the Dark." Journal of West Indian Literature (1999): 2-9.

[6] Bhabha, Homi K. The location of culture. Psychology Press, 1994.print

[7] Dawson, Ashley. Mongrel Nation: Diasporic Culture and the making of postcolonial Britain. University of Michigan Press, 2007.

[10] MacLeod, Lewis. "'You have to start thinking all over again": Masculinities, Narratology and New Approaches to Sam Selvon. ARIEL: A Review of International English Literature 36.1-2 (2005).

[16] Kanneh, Kadiatu. "Racism and culture." Paragraph 16.1 (1993): 34-46. 